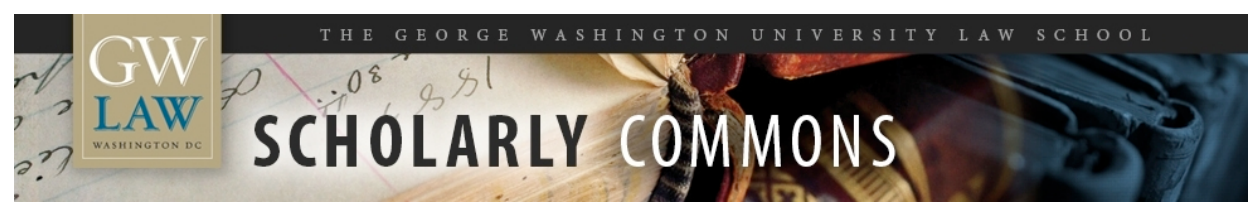

\title{
International Trade Agreements and U.S. Procurement Law
}

Christopher R. Yukins

George Washington University Law School, cyukins@law.gwu.edu

Allen B. Green

Follow this and additional works at: https://scholarship.law.gwu.edu/faculty_publications

Part of the Law Commons

\section{Recommended Citation}

Yukins, Christopher R. and Green, Allen, International Trade Agreements and U.S. Procurement Law (2018). GWU Law School Public Law Research Paper No. 2019-55; GWU Legal Studies Research Paper No. 2019-55. Available at SSRN: https://ssrn.com/abstract=3443244

This Article is brought to you for free and open access by the Faculty Scholarship at Scholarly Commons. It has been accepted for inclusion in GW Law Faculty Publications \& Other Works by an authorized administrator of Scholarly Commons. For more information, please contact spagel@law.gwu.edu. 
[NOTE: This is a draft of Chapter 9 to The Contractor's Guide to

International Procurement (American Bar Association 2018) (Erin

Loraine Felix \& Marques Peterson, eds.), available at

https://www.americanbar.org/products/inv/book/350817442/.]

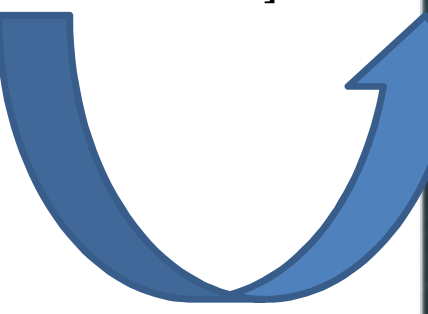

\title{
International Trade Agreements and U. S. Procurement Law
}

\author{
Christopher R. Yukins \& Allen B. Green*
}

\section{Introduction and Summary}

Some of the most difficult issues in U.S. procurement law stem from the nation's several centuries of accumulated protectionist measures, and from a patchwork of trade agreements meant to contain that protectionism. These conflicting measures reflect a pushand-pull in U.S. procurement policy, between those who favor closed procurement markets and those who favor open competition; the compromises reached between the two camps have created a Byzantine set of rules and requirements. At the same time, though, this area of law holds a special promise for the future of procurement, for cross-border agreements currently offer the readiest means of erasing anti-competitive differences between national rules, by bringing many nations to a common standard of international best practice.

To make sense of this complex area, this chapter proceeds in three parts. Part II reviews the major pieces of protectionist legislation passed by Congress, ${ }^{1}$ focusing first on the

\footnotetext{
* Christopher Yukins is the Lynn David Research Professor in Government Procurement Law at the George Washington University Law School, and co-director of the Government Procurement Law Program there. Allen Green is a partner in the Washington, D.C. offices of Dentons, an international law firm, and the author of International Government Contract Law (Thomson Reuters, available through Westlaw). Messrs. Green and Yukins co-teach a seminar on foreign government contracting at George Washington University Law School.

${ }^{1}$ This chapter focuses on federal legislation which imposes domestic preferences. For a survey of state and local measures, see Yuhua Qiao, Khi Thai \& Glenn Cummings, State and Local Procurement Preferences: A Survey,
} 
Buy American Act of 1933; this discussion also references some of the most important implementing regulations. Part III reviews the most important U.S. trade agreements which have limited the force of that protectionist legislation, including the World Trade Organization's Agreement on Government Procurement (GPA). ${ }^{2}$ Because barriers to procurement can also arise from structural factors -- "non-tariff barriers to trade" which, in practice, may protect domestic vendors -- this part also explains how the trade agreements mitigate those non-tariff barriers. Finally, Part IV concludes by offering some practical suggestions for those working in this field, and suggests a possible road ahead for cooperation in international procurement markets.

\section{Major Protectionist Measures in U.S. Law}

In assessing major laws which protect the U.S. federal procurement market, it is worth noting that this type of protectionism stretches back throughout the history of the United States. $^{3}$ Indeed, even Adam Smith (whose free-market arguments helped shape the early economic policies of the United States) argued for special protections in trade involving military materiel, because of the national security implications of allowing foreign nations to

9 J. Pub. Proc. 371 (2009); Kingsley S. Osei, The Best of Both Worlds: Reciprocal Preference and Punitive Retaliation in Public Contracts, 40 Pub. Cont. L.J. 715 (2011) (reviewing state preferences).

2 Although the current text is formally the Revised Agreement on Government Procurement, it is popularly referred to as the "Government Procurement Agreement," or "GPA." For an introduction to the GPA, with links to predecessor versions of the agreement, see the World Trade Organization website at https://www.wto.org/english/tratop_e/gproc_e/gp_gpa_e.htm.

${ }^{3}$ Over a century ago, for example, Congress required that dredging in U.S. waters be done only by U.S.-registered vessels, see The Dredging Act, Ch. 2566, Sec. 1, 34 Stat. 206 (1906) (“A foreign-built dredge shall not, under penalty of forfeiture, engage in dredging in the United States unless documented as a vessel of the United States."); that preference that may have stemmed from the role that dredging played in the country's early history, in national defense and economic development, see, e.g., U.S. Army Corps of Engineers, A Brief History, http://www.usace.army.mil/About/History/BriefHistoryoftheCorps/ImprovingTransportation.aspx. Today, the U.S. government still excludes dredging from U.S. free trade agreements, see, e.g., Agreement on Government Procurement, U.S. Annexes, Annex 6 ("This Agreement does not cover procurement of dredging services."), available at https://www.wto.org/english/tratop_e/gproc_e/gp_app_agree_e.htm\#revisedGPAm, despite massive changes in the national economy, and despite pressure from the United States' trading partners to open federal dredging contracts to foreign competition, see, e.g., Daniel J. Ikenson, A Ports Policy Barnacled With Bad Law, Wall St. J., Aug. 4, 2015 (noting pressure from European negotiators to open U.S. dredging markets), available at http://www.wsj.com/articles/a-ports-policy-barnacled-with-bad-law-1438730822. 
control critical supplies. ${ }^{4}$ As a practical matter, domestic preferences in procurement are deeply embedded in U.S. politics and law, and, once in place, are difficult to erase.

\section{A. The Buy American Act}

The Buy American $\mathrm{Act}^{5}$ was passed by Congress in 1933 as part of a broader protectionist reaction to the Great Depression. ${ }^{6}$ The Act generally requires federal agencies to purchase only U.S. materials and manufactured goods. ${ }^{7}$ Under the Act, as implemented in federal regulations (discussed below), manufactured products made wholly in the United States, or products from "substantially all" domestic components, are eligible for price preferences over foreign products. ${ }^{8}$ The Buy American Act's preferences turn on the place of manufacture of the products (or the source of raw materials), and not the nationality of the contractor. The Buy American Act applies to the federal government's direct purchases exceeding the micro-purchase threshold (currently $\$ 3,000),{ }^{9}$ and applies where a preference is consistent with the public interest, and the proffered items are reasonable in cost. ${ }^{10}$ The margin

\footnotetext{
${ }^{4}$ See Adam Smith, The Wealth of Nations, Book IV, Ch. II (1776) ("There seem, however, to be two cases in which it will generally be advantageous to lay some burden upon foreign for the encouragement of domestic industry. The first is, when some particular sort of industry is necessary for the defence of the country.").

541 U.S.C. $\S \S 8301-8305$. The core provision of the Buy American Act, 41 U.S.C. $\S 8302$, states in relevant part:
}

(1) Allowable materials.--Only unmanufactured articles, materials, and supplies that have been mined or produced in the United States, and only manufactured articles, materials, and supplies that have been manufactured in the United States substantially all from articles, materials, or supplies mined, produced, or manufactured in the United States, shall be acquired for public use unless the head of the department or independent establishment concerned determines their acquisition to be inconsistent with the public interest or their cost to be unreasonable.

${ }^{6}$ Allen B. Green, International Government Contract Law § 2:4, Historical "Buy National" Legislation-The "Buy American" Act (Thomson Reuters 2015) (available on Westlaw).

7 See generally John R. Luckey, Domestic Content Legislation: The Buy American Act and Complementary Little Buy American Provisions 2 (Cong. Res. Serv. Rep. No. R42501, Sept. 2012), available at https://www.fas.org/sgp/crs/misc/R42501.pdf.

8 See, e.g., Jean Heilman Grier, Trade Implications of the Buy American Act of 1933 (July 21, 2014), http://trade.djaghe.com/?p=731.

941 U.S.C. § 1902 (definition of micropurchase); 41 U.S.C. $8302(A)(2)(C)$ (Buy American Act exception).

${ }^{10}$ The Buy American Act is implemented through FAR Subpart 25.1, discussed infra. 
of preference applicable to U.S. goods is 6 to 12 percent in the civilian agencies, ${ }^{11}$ and up to 50 percent in Defense Department procurements. ${ }^{12}$ There are three major statutory exemptions to the Buy American requirements: (1) for supplies or materials purchased for use outside the United States; (2) for supplies or materials which are not available in the United States in commercially reasonable quantities or satisfactory quality; and (3) to purchases under the micro-purchase threshold (as noted). ${ }^{13}$

Other important exceptions to the Buy American Act are explained in the implementing regulations. ${ }^{14}$ For example, while normally to qualify as "American" under the Act, the cost of domestic components of a manufactured item must exceed 50 percent of the cost of all components, under FAR 25.101(a)(2) that requirement has been waived for acquisitions of commercial off-the-shelf (COTS) items. ${ }^{15}$ To qualify as "COTS," items must be sold in substantial quantities in the commercial marketplace. ${ }^{16}$ This special exception from the Buy American Act's requirements -- one of the few exceptions extended to COTS items ${ }^{17}$-- reduces compliance costs for commercial vendors selling COTS items to the federal government.

The implementing regulations for the Buy American Act are divided into two subparts. FAR Subpart 25.1 applies the Buy American Act to supplies, and includes lists of products that are considered "nonavailable" in the U.S. market, and so are not covered by the Act. ${ }^{18}$ Subpart 25.1 also exempts information technology that qualifies as "commercial items" from

\footnotetext{
${ }^{11}$ FAR 25.105.

${ }^{12}$ DFARS 225.105.

1341 U.S.C. $\S 8302(a)(2)$.

${ }^{14}$ See Allen B. Green, supra note 6, § 2:5, Historical "Buy National" Legislation-The "Buy American" ActRequirements of the BAA.

15 This implements the COTS exception under 41 U.S.C. $\S 1907$.

${ }^{16}$ See FAR 2.101 (definitions).

1774 Fed. Reg. 2713 (2009).

18 FAR 25.104.
} 
the Buy American Act. ${ }^{19}$ Subpart 25.2, which covers construction supplies, extends a similar exception for commercial-item information technology used on construction projects. ${ }^{20}$

\section{B. "Buy American" Requirements Under the Recovery Act}

A recurring point of confusion is the "Buy American" provision in the American Recovery and Reinvestment Act (ARRA), ${ }^{21}$ also known as the Recovery Act. The Recovery Act, passed in 2009, injected a massive fiscal stimulus into the U.S. economy, which was then mired in recession. ${ }^{22}$ Under section 1605 of the Recovery Act, a domestic content requirement was attached to all Recovery Act funds, not only for federal agencies but also for other entities using those funds. Specifically, section 1605 of the Recovery Act prohibited use of funds appropriated or otherwise made available by the act unless all of the iron, steel, and manufactured goods used in the project were produced in the United States. Although the Recovery Act requirement was not part of the original Buy American Act, discussed above, section 1605 (to the confusion of many) referred to this as a "Buy American" requirement.

Subpart 25.6 of the Federal Acquisition Regulation implemented section 1605 for federal procurement carried out using Recovery Act funds, and the Office of Management and Budget separately published guidance ${ }^{23}$ for grantees' use of Recovery Act funds. The Recovery Act's "Buy American" provision was controversial, ${ }^{24}$ in part because section 1605's

\footnotetext{
${ }^{19}$ FAR 25.103(e).

${ }^{20}$ FAR 25.202(a)(4).

21 Pub. L. No. 111-5.

22 See generally John R. Luckey, supra note 7, at 16.

232 C.F.R. $\S 176.60$ et seq.

${ }^{24}$ See generally Kameron Hillstrom, The American Recovery and Reinvestment Act: A Fitting Future for Recovery Legislation, 44 Pub. Cont. L.J. 285 (2015); Steven L. Briggerman, Buy American Requirements Under the Recovery Act: The Final Rules, 25 Nash \& Cibinic Rep. II 1 (2011); Thomas D. Blanford, Navigating the Recovery Act's Buy American Rule in State and Local Government Construction, Procurement Law. 3 (Fall 2010); Steven L. Schooner \& Christopher R. Yukins, Feature Comment: Tempering “Buy American” in the Recovery Act -Steering Clear of a Trade War, 51 Gov. Cont. II 78 (Thomson Reuters, Mar. 11, 2009).
} 
domestic content requirements had the practical effect of slowing projects -- despite the Act's stated goal of providing a quick fiscal stimulus to the U.S. economy. ${ }^{25}$

\section{Other Protectionist U.S. Legislation}

Congress has also imposed a number of "Buy America" requirements on procurements done under certain forms of federal funding, often in transportation programs. ${ }^{26}$ Some of the more prominent include:

- Projects Funded by the Federal Transit Administration and the Federal Highway Administration: The steel, iron, and manufactured goods used in all Federal Transit Administration-funded projects must be produced in the United States. ${ }^{27}$ The legislation allows for limited waivers, if for example the use of domestic materials will drive up the cost of a project by 25 percent or more. The legislation also imposes automatic debarment on anyone who intentionally misrepresents that a product purchased with funds under the act was "Made in America." ${ }^{28}$ The federal Department of Transportation is explicitly barred from limiting states' ability to impose even more stringent requirements on foreign

${ }^{25}$ See, e.g., U.S. Government Accountability Office, Recovery Act: Project Selection and Starts Are Influenced by Certain Federal Requirements and Other Factors, GAO-10-383 (Feb. 2010).

${ }^{26}$ Many of these special legislative provisions imposing domestic preferences are discussed in John Luckey, supra note 7, at 2-8. See also Jean Heilman Grier, Federal Domestic Content Restrictions on State \& Local Projects (2014), available at http://trade.djaghe.com/?p=2594. The political aspects of these "Buy America" requirements are suggested in the Department of Transportation's description, on its website, at https://www.transportation.gov/highlights/buyamerica:

The Department of Transportation is committed to maximizing the economic benefits of the Obama Administration's historic infrastructure investments through Buy America provisions that keep American companies healthy and families working.

Buy America provisions ensure that transportation infrastructure projects are built with American-made products. That means that Department of Transportation investments are able to support an entire supply chain of American companies and their employees.

${ }^{27} 49$ U.S.C. § 5323(j).

${ }^{28} I d$. 
goods and materials used in FTA-funded projects. ${ }^{29}$ Similar restrictions apply to projects funded by the Federal Highway Administration. ${ }^{30}$

- Amtrak Rail Projects: The National Railroad Passenger Corporation, which operates the national passenger rail system doing business as Amtrak, is subject to a federal statute which requires that Amtrak buy raw materials mined or produced in the United States, or manufactured articles, material, and supplies manufactured in the United States substantially from articles, material, and supplies mined, produced, or manufactured in the United States. ${ }^{31}$ Again, limited waivers are available, such as where the use of domestic materials would be unreasonably costly. ${ }^{32}$

- Intercity Rail Projects -- Federal Railroad Administration: Under law, the Secretary of Transportation may fund intercity rail projects only if the steel, iron, and manufactured goods used in the project are produced in the United States. ${ }^{33}$ The statutory provisions allow limited waivers, much like those discussed above regarding other transportation funding legislation. ${ }^{34}$

- Projects Funded by the Federal Aviation Administration: For some projects funded by the FAA, only steel and manufactured goods produced in the United States may be used. ${ }^{35}$ Moreover, the FAA may shift certain contracts to a

${ }^{29} \mathrm{Id}$.

3023 U.S.C. $\$ 313$.

3149 U.S.C. $§ 24305(\mathrm{f})$.

${ }^{32} I d$.

3349 U.S. $\S 24405$.

${ }^{34} I d$.

3549 U.S.C. $§ 50101$. The FAA’s "Buy America” requirements are discussed at a website sponsored by the U.S. Department of Transportation, https:/www.transportation.gov/highlights/buyamerica. 
domestic firm if the FAA Administrator, the U.S. Secretary of Commerce and the U.S. Trade Representative concur that doing so is in the public interest. ${ }^{36}$

Finally, Congress has imposed additional special domestic content requirements for particular kinds of purchases, ranging from photovoltaic devices to goods purchased for disaster relief. ${ }^{37}$ For example, under legislation popularly known as the Berry Amendment, the Department of Defense and specific units of the Department of Homeland Defense are barred from buying textiles, clothing and certain other materials from abroad. ${ }^{38}$ Another, related prohibition applies to foreign "specialty metals," which may not be used for certain important categories of items (such as tanks, weapons systems or aircraft) purchased by the Defense Department, unless certain exceptions apply. ${ }^{39}$

The discussion above cannot, of course, cover all domestic preferences in federal procurement. Instead, the discussion is meant to show the diversity of domestic preferences that have been incorporated into federal law over the years, and to highlight some of the most important (or well known) among those. While many of these preferences have been preserved through special exceptions to international trade agreements (discussed infra), the sheer number and importance of the preferences help explain the key liberalizing legislation (the Trade Agreements Act) and trade agreements discussed below.

\section{The Trade Agreements Act}

\footnotetext{
3649 U.S.C. $\$ 50103$.

${ }^{37}$ See generally John Luckey, supra note 7, at 6-8.

${ }^{38}$ See Allen B. Green, supra note 6, § 2:17, Historical "Buy National” Legislation—The "Buy American" ActManufactured articles-Other U.S. buy national preferences-The Berry Amendment.

${ }^{39}$ See Allen B. Green, supra note 6, § 2:18, Historical "Buy National” Legislation-The "Buy American" ActManufactured articles-Other U.S. buy national preferences-Specialty metals statute.
} 
The Trade Agreements Act (TAA) ${ }^{40}$ implements various free trade agreements that directly affect procurement. ${ }^{41}$ Among other things, the TAA authorizes the President to waive the Buy American Act's domestic preference for products from countries which have entered into a trade agreement with which the United States or which otherwise meet certain eligibility criteria. ${ }^{42}$ The country of origin under the TAA (unlike the Buy American Act) typically turns on where the article has been "substantially transformed," i.e., where it has been transformed into "a new and different article of commerce, with a name, character, or use distinct from the original article."43

The TAA also allows bars purchases from certain nations that have not entered into trade agreements with the United States (nations that are not "designated"). The President's general authority under the Trade Agreements Act to bar procurement from nations that are not "designated" is addressed at 19 U.S.C. $§ 2512(a) .{ }^{44}$ That general bar creates what has been

4019 U.S.C. chap. 13.

${ }^{41} 19$ U.S.C. $\$ 2502 ;$ see, e.g., Steven W. Feldman, Government Contracts Guidebook $\S 8: 33$. Trade Agreements Act $\left(4^{\text {th }}\right.$ ed. 2015); Allen B. Green, supra note $6, \S 2: 29$, The development of international free trade in government contracts-The U.S. Trade Agreements Act and its implementation.

4219 U.S.C. § 2511; see, e.g., John A. Howell, The Trade Agreements Act of 1979 Versus the Buy American Act: The Irresistible Force Meets the Immovable Object, 35 Pub. Cont. L.J. 495, 500 (2006); Allen B. Green, supra note 6, § 2.39, Interplay between BAA and Trade Agreements Act.

${ }^{43}$ FAR 25.001(c) describes the differing tests for determining country of origin under the Buy American Act and the trade agreements:

(c) The test to determine the country of origin for an end product under the Buy American statute (see the various country "end product" definitions in 25.003) is different from the test to determine the country of origin for an end product under the trade agreements, or the criteria for the representation on end products manufactured outside the United States (see 52.225-18).

(1) The Buy American statute uses a two-part test to define a "domestic end product" or "domestic construction material" (manufactured in the United States and a formula based on cost of domestic components). The component test has been waived for acquisition of commercially available off-the-shelf items.

(2) Under the trade agreements, the test to determine country of origin is "substantial transformation" (i.e., transforming an article into a new and different article of commerce, with a name, character, or use distinct from the original article)....

${ }^{44} 19$ U.S.C. § 2512(a) states:

(a) Authority to bar procurement from non-designated countries 
called the "walled garden" of U.S. procurement. ${ }^{45}$ The "wall" is not an absolute bar, for vendors from certain least-developed nations ${ }^{46}$ and Caribbean Basin Initiative nations ${ }^{47}$ (discussed below) also may sell to the U.S. government, as may vendors selling defense materiel from "qualifying countries" that have entered into reciprocal defense procurement agreements with the U.S. Department of Defense (see below). ${ }^{48}$

Some of the agreements covered by the TAA, discussed further below, are the WTO Government Procurement Agreement (GPA), the North American Free Trade Agreement (NAFTA), and various bilateral and regional free trade agreements (FTAs). With regard to the

(1) In general. Subject to paragraph (2), the President, in order to encourage additional countries to become parties to the Agreement [on Government Procurement] and to provide appropriate reciprocal competitive government procurement opportunities to United States products and suppliers of such products-

(A) shall, with respect to procurement covered by the Agreement, prohibit the procurement . . . of products-

(i) which are products of a foreign country or instrumentality which is not designated pursuant to section 2511(b) of this title, and

(ii) which would otherwise be eligible products; and

(B) may, with respect to procurement covered by the Agreement, take such other actions within the President's authority as the President deems necessary.

(2) Exception. Paragraph (1) shall not apply in the case of procurements for which-

(A) there are no offers of products or services of the United States or of eligible products; or

(B) the offers of products or services of the United States or of eligible products are insufficient to fulfill the requirements of the United States Government.

${ }^{45}$ See FAR 25.403(c)(1) ("Under the Trade Agreements Act (19 U.S.C. 2512), in acquisitions covered by the WTO GPA, acquire only U.S.-made or designated country end products or U.S. or designated country services, unless offers for such end products or services are either not received or are insufficient to fulfill the requirements. This purchase restriction does not apply below the WTO GPA threshold for supplies and services, even if the acquisition is covered by an FTA."); Christopher R. Yukins \& Steven L. Schooner, Incrementalism: Eroding the Impediments to a Global Public Procurement Market, 38 Geo. J. Int'l L. 529, 569 (2007).

${ }^{46}$ FAR 25.404 ("For acquisitions covered by the WTO GPA, least developed country end products, construction material, and services must be treated as eligible products," i.e., must be afforded access).

${ }^{47}$ FAR 25.405 ("Under the Caribbean Basin Trade Initiative, the United States Trade Representative has determined that, for acquisitions covered by the WTO GPA, Caribbean Basin country end products, construction material, and services must be treated as eligible products.").

${ }^{48} 19$ U.S.C. $\S 2512(b)(3) ;$ FAR 25.403(c)(2); DFARS 225.003(1); DFARS 225.403. 
GPA (the most prominent of the trade agreements involving procurement), President Jimmy Carter delegated his waiver authority to the U.S. Trade Representative under Executive Order $12260,{ }^{49}$ and the U.S. Trade Representative has in turn waived the application of the Buy American Act to procurements covered by the GPA and other free trade agreements. ${ }^{50}$

The TAA gives the President broad authority to waive "the application of any law, regulation, procedure, or practice" that could discriminate against suppliers from nations that are parties to the GPA or the various FTAs. In principle, this authority would appear to cover any protectionist law or provision (such as those discussed above). In practice, however, the TAA authority (as delegated) has been much more narrowly applied, to waive only the Buy American Act and the U.S. Department of Defense's Balance of Payments Program. ${ }^{51}$

With regard to socioeconomic preferences, by its terms the TAA authority cannot be used to waive "any small business or minority preference." 52 Such preferences cover a significant portion of U.S. federal procurement. Congress has required that federal agencies award at least 23 percent of all federal procurement dollars to small businesses, ${ }^{53}$ and because only U.S.-based businesses can qualify as "small," 54 this small business contracting goal in effect raises a significant barrier to foreign competition. Because the U.S. cannot waive this

\footnotetext{
4946 Fed. Reg. 1653 (Dec. 31, 1980).

${ }^{50}$ See FAR 25.402(a) ("The President has delegated this waiver authority to the U.S. Trade Representative. In acquisitions covered by the WTO GPA, Free Trade Agreements, or the Israeli Trade Act, the U.S. Trade Representative has waived the Buy American statute and other discriminatory provisions for eligible products. Offers of eligible products receive equal consideration with domestic offers.").

${ }^{51}$ See Jean Heilman Grier, Trade Agreements Act of 1979: Broad Authority, Narrow Application (Apr. 21, 2014), http://trade.djaghe.com/?p=559. The Buy American Act is discussed above; the Defense Department's Balance of Payments Program, which calls for the purchase of U.S. supplies and construction materials by the Defense Department abroad, is described at DFARS Subpart 225.75.

5249 U.S.C. § 2511(f).

${ }^{53} 15$ U.S.C. 644(g)(1)(A)(1) ("The Governmentwide goal for participation by small business concerns shall be established at not less than 23 percent of the total value of all prime contract awards for each fiscal year.").

${ }^{54}$ See 13 C.F.R. § 121.105(a)(1) ("a business concern eligible for assistance from SBA as a small business is a business entity organized for profit, with a place of business located in the United States, and which operates primarily within the United States or which makes a significant contribution to the U.S. economy through payment of taxes or use of American products, materials or labor.").
} 
requirement for procurements covered by its trade agreements, it must exclude these small business preferences from its commitments. In doing so, the United States defines a set-aside broadly to include any form of preference. ${ }^{55}$ This reservation for small and disadvantaged businesses has been explicitly recognized and preserved in the WTO Agreement on Government Procurement, which is discussed in the next Part.

\section{Key International Trade Agreements and Initiatives Regarding Procurement}

As noted, the most prominent of the trade agreements which affect federal procurement is the WTO Agreement on Government Procurement, commonly referred to as the "Government Procurement Agreement" or the "GPA.""56 The discussion below reviews the GPA and several other free trade agreements that, as is described below, are now reflected in the Federal Acquisition Regulation (FAR).

For those working in U.S. federal procurement, the implementing statutes and the terms of the FAR (and its agency-specific supplements) are, in practical terms, the most important measures of the trade agreements' scope. Although the trade agreements discussed below are international obligations and so should be read to give effect to their plain meaning, ${ }^{57}$ and (absent express congressional language to the contrary) domestic law should not be read to conflict with those international obligations, ${ }^{58}$ ultimately contracting and oversight officials (including the Government Accountability Office (GAO)) are likely to give much more weight

\footnotetext{
${ }^{55}$ WTO Revised GPA, U.S. Annex 7 (General Notes), para. 1 ("This Agreement does not apply to any set aside on behalf of a small- or minority-owned business. A set-aside may include any form of preference, such as the exclusive right to provide a good or service, or any price preference.").

${ }^{56}$ See generally Allen B. Green, supra note 6, § 2:33. The World Trade Organization (WTO) Government Procurement Agreement.

${ }^{57}$ United Tech. Corp. v. United States, 315 F.3d 1320, 1322 (Fed. Cir. 2003) ("The terms of a treaty are to be given their ordinary meaning in the context of the treaty, and are to be interpreted to best fulfill the purpose of the treaty. . . . This general rule of construction also applies to international agreements, for which we will more strictly construe the agreement's plain meaning.").

${ }^{58}$ E.g., Federal-Mogul Corp. v. United States, 63 F.3d 1572, 1581 (Fed. Cir. 1995).
} 
to the federal statutes and regulations. ${ }^{59}$ Thus, while individual trade agreements may reflect detailed compromises and negotiations, because of the sheer volume of buying in the $\$ 500$ billion procurement system and the intimidating complexity of the patchwork of agreements, in any given procurement contracting officials are likely to look first to the terms of the implementing statutes, regulations and solicitation provisions, and not to the agreements themselves. The discussion here therefore focuses on the FAR, which sets forth both implementing guidance for contracting officials (in Part 25), and implementing clauses for inclusion in solicitations (in Part 52).

The basic means of implementing the various trade agreements is simple: under authority of the Trade Agreements Act (discussed above), delegated by the President to the U.S. Trade Representative, the government waives certain domestic preferences (in the United States, primarily the Buy American Act) for covered procurements above an agreed monetary threshold. ${ }^{60}$ For federal procurements, the acquisition threshold values are set forth in FAR

\footnotetext{
${ }^{59}$ The questions of direct enforcement of international agreements regarding procurement, and of the relative precedence of international agreements, U.S. statutes and regulations, are generally outside the scope of this chapter. It is worth highlighting, though, recent bid challenges to the award of a U.S. Air Force contract in Greenland to the Danish-registered subsidiary of a U.S. company, despite a longstanding U.S.-Danish agreement that such awards were to be made only to Danish or Greenlandic companies. In its decision denying an initial protest, GAO focused on the eligibility terms of the Air Force solicitation, which GAO noted were strictly met by the awardee. Per Aarsleff a/s, Comp. Gen. B-410782 (Feb. 18, 2015). In sustaining a follow-on bid protest to the U.S. Court of Federal Claims, Per Aarsleff A/S v. United States, 121 Fed. Cl. 603, 622 (2015), the court held that the "treaty bar" of 28 U.S.C. $§ 1502$, which bars the Court of Federal Claims from adjudicating claims under international treaties and agreements, did not apply because the court was merely using the U.S.-Danish agreement as a tool in interpreting the terms of the governing solicitation. $121 \mathrm{Fed}$. Cl. at 622 . On appeal of that decision, the U.S. Court of Appeals for the Federal Circuit reversed on the narrower ground that the solicitation's description of eligible contractors was patently ambiguous, and so should have been protested before award. Per Aarsleff A/S v. United States, Fed. Cir. No. 2015-5111, 2016 WL 3869790 (June 23, 2016).

${ }^{60}$ FAR 25. 25.402(a)(1) states:
}

(a)(1) The Trade Agreements Act (19 U.S.C. 2501, et seq.) provides the authority for the President to waive the Buy American statute and other discriminatory provisions for eligible products from countries that have signed an international trade agreement with the United States, or that meet certain other criteria, such as being a least developed country. The President has delegated this waiver authority to the U.S. Trade Representative. In acquisitions covered by the WTO GPA, Free Trade Agreements, or the Israeli Trade Act, the U.S. Trade Representative has waived the Buy American statute and other discriminatory provisions for eligible products. Offers of eligible products receive equal consideration with domestic offers. 
25.402 ; those thresholds currently range from $\$ 25,000$ (for supplies from Canada under NAFTA) to over $\$ 10$ million (for construction contracts being bid on by firms from Bahrain and other countries). The FAR sets forth rules for contracting officials calculating the prospective value of an acquisition. Those rules generally call for a liberal approach to forecasting the value of an acquisition, and say if "there is any doubt as to the contemplated term of the contract, use the estimated monthly payment multiplied by $48 . " 61$ The FAR says that if "recurring or multiple awards for the same type of product or products are anticipated," then the contracting official should "use the total estimated value of these projected awards to determine whether" an agreement applies. "Do not," the FAR admonishes, "divide any acquisition with the intent of reducing the estimated value of the acquisition below the dollar threshold of the WTO GPA or an FTA." 62

While the underlying trade agreements may reflect more nuanced compromises as to the agencies and categories of goods and services covered, the FAR takes a simpler and more expansive approach: the FAR does not exclude any executive agency ${ }^{63}$ from coverage and, using a "negative list" approach, the FAR excludes only certain narrow categories of services from coverage. ${ }^{64}$ The requirements regarding free trade agreements do not, however, apply to acquisitions set aside for small businesses, or to "arms, ammunition, or war materials, or purchases indispensable for national security or for national defense purposes." ${ }^{65}$ Nor do the trade agreements apply to acquisitions of end products for resale, acquisitions from Federal

\footnotetext{
${ }^{61}$ FAR 25.403(b)(1)(iv).

${ }^{62}$ FAR 25.403(b)(3).

${ }^{63}$ See FAR 1.101 ("The Federal Acquisition Regulations System is established for the codification and publication of uniform policies and procedures for acquisition by all executive agencies.").

${ }^{64}$ FAR 25.401(b).

${ }^{65}$ FAR 25.401(a).
} 
Prison Industries, acquisitions from nonprofit agencies employing people who are blind or severely disabled, or to certain other acquisitions not using full and open competition. ${ }^{66}$

Similarly, while the underlying trade agreements may include much more detailed provisions regarding the procedures to be used in procurement (discussed below), the FAR's provisions regarding how agencies are to implement the trade agreements are relatively sparse and simple. FAR 25.402(a)(1) says that offers of "eligible products" -- goods and services covered by a trade agreement -- are to "receive equal consideration with domestic offers." 67 FAR 25.403(a) echoes that requirement that eligible products "from WTO GPA and FTA countries are entitled to the nondiscriminatory treatment specified in 25.402(a)(1)," and notes that the "WTO GPA and FTAs specify procurement procedures designed to ensure fairness," citing FAR 25.408.

In turn, FAR 25.408 states that if a trade agreement applies in a particular procurement, the contracting officer must comply with certain requirements -- requirements, for the most part, which would apply to federal procurements as a matter of course -- such as publicizing, response time, currency, language, and notices of opportunities and awards. ${ }^{68}$ FAR 25.408(a)(3) does go a step further regarding foreign offers, and says that an agency must not "include technical requirements in solicitations solely to preclude the acquisition of eligible products" (emphasis added). That provision barring intentionally discriminatory technical standards is, however, not as broad as Article $\mathrm{X}$ of the underlying GPA (discussed below), which says that a procuring agency "shall not prepare, adopt or apply any technical

\footnotetext{
${ }^{66}$ FAR 25.401(a)(5).

${ }^{67}$ FAR 25.003 states, in relevant part: “'Eligible product' means a foreign end product, construction material, or service that, due to applicability of a trade agreement to a particular acquisition, is not subject to discriminatory treatment."

${ }^{68}$ FAR 25.408(a).
} 
specification .. . with the purpose or the effect of creating unnecessary obstacles to international trade" (emphasis added). ${ }^{69}$

To make better sense of this interplay between the implementing FAR and the underlying trade agreements, the discussion below reviews the various trade agreements in more detail. It should be emphasized, however, that U.S. law is not yet settled on what force, if any, the underlying agreements will be given by U.S. courts and GAO, in a bid protest or otherwise. What is clear (as discussed below) is that the GPA and the other international trade agreements are emerging as agreed compilations of international best practices in procurement. In the long term, therefore, these trade agreements may be integrated more directly into the fabric of U.S. procurement law and practice, to reduce regulatory barriers to international trade in procurement.

\section{A. The World Trade Organization's Agreement on Government Procurement (GPA)}

The Agreement on Government Procurement (GPA) ${ }^{70}$ is a plurilateral agreement under the World Trade Organization, which has a main aim of mutually opening member nations' government procurement markets. ${ }^{71}$ Membership in the Agreement is open to all WTO member states, but currently not all WTO members are parties to the Agreement. Upon accession by a party, the GPA is a binding international agreement and is enforceable through a party's domestic review mechanism (if the GPA is given direct effect) and the WTO's dispute

\footnotetext{
${ }^{69}$ Available at https://www.wto.org/english/docs_e/legal_e/rev-gpr-94_01_e.htm.

${ }^{70}$ See, e.g., Sue Arrowsmith, Government Procurement in the WTO (Kluwers 2003) (covering the GPA before the 2012 revision to the GPA); The WTO Regime on Government Procurement: Challenge and Reform (Sue Arrowsmith \& Robert D. Anderson, eds., Cambridge U. Press 2011) (comprehensive set of essays on the revised GPA). For a discussion of the most recent revisions to the GPA, in the version which was signed in 2012, see Robert D. Anderson, Steven L. Schooner \& Collin D. Swan, Feature Comment: The WTO's Revised Government Procurement Agreement -- An Important Milestone Toward Greater Market Access And Transparency In Global Public Procurement Markets, 54 Gov't Contr. I1 (Jan. 11, 2012). For updates on the WTO Government Procurement Agreement, see the blog maintained by author Jean Grier at http://trade.djaghe.com/?page_id=310. ${ }^{71}$ See World Trade Organization, Agreement on Government Procurement: Parties, Observers and Accessions, https://www.wto.org/english/tratop_e/gproc_e/memobs_e.htm; Allen B. Green, supra note 6, § 2:35, The World Trade Organization (WTO)_-The WTO Government Procurement Agreement.
} 
settlement mechanism. ${ }^{72}$ The Agreement comprises two parts: the main text which sets minimum standards for nondiscriminatory procurement procedures, and the schedules of commitments for each party's market access. While the text of the Agreement establishes rules for "open, fair and transparent" competitive procedures in government procurement, the schedules of commitments limit the applicability of these rules to only those goods, services and works, and public bodies, listed in the schedules.

The procedures required by the GPA are important, for as more nations join the GPA, the GPA's minima are increasingly becoming the benchmark for procurement rules around the world. ${ }^{73}$ Beyond the core requirements under GPA Article IV that parties to the agreement not discriminate between other parties ("non-discrmination") and treat vendors from GPA parties as they would treat their own vendors ("national treatment"), the agreement also sets minimum requirements for, among other things, publicizing information on a party's procurement laws

\footnotetext{
${ }^{72} I d$. Whether the GPA and other free trade agreements (FTAs) are directly enforceable by bid protest brought in the Unite States, for example by a foreign vendor wishing to challenge an apparently discriminatory provision of a U.S. solicitation, is an issue that has not been squarely addressed under U.S. law and (as noted) is generally outside the scope of this chapter; see supra note 59. As the U.S. Court of Appeals for the Third Circuit noted in Gross v. German Foundation Industrial Initiative, 549 F.3d 605 (3d Cir. 2008), to "ascertain whether an international agreement creates a private cause of action, we first look to the text of the agreement." Id. at 612 . The language of the GPA is ambiguous on this point, however, for while it says that each "Party shall provide a timely, effective, transparent and non-discriminatory administrative or judicial review procedure through which a supplier may challenge ... a breach of the Agreement," the GPA also says that "where the supplier does not have a right to challenge directly a breach of the Agreement under the domestic law of a Party," the GPA party must still allow vendors a forum to challenge "a failure to comply with a Party's measures implementing this Agreement." Whatever the applicable rule in federal procurement, a foreign vendor challenging an allegedly discriminatory provision might well begin with FAR 25.403(a), discussed above, which says that eligible products "from WTO GPA and FTA countries are entitled to the nondiscriminatory treatment specified in [FAR] 25.402(a)(1)," and the "WTO GPA and FTAs specify procurement procedures designed to ensure fairness (see 25.408)." The procedures specified by the international agreements are discussed further below; how ultimately the question of direct enforceability might be resolved under U.S. law is, however, beyond the scope of this chapter.

${ }^{73}$ The model procurement law which was prepared by the United Nations Commission on International Trade Law (UNCITRAL), for example, was written to ensure that it conformed where possible to the revised GPA. See UNCITRAL, Guide to Enactment of the UNCITRAL Model Law on Public Procurement (2014). Similarly, the procurement provisions in chapter 15 of the currently pending Trans-Pacific Partnership (TPP) agreement (discussed below) were based, in large part, on the language of the revised GPA. See Jean Heilman Grier, Revised GPA as Model for TPP Procurement Rules (Jan. 23, 2014), http://trade.djaghe.com/?p=374.
} 
and regulations (Article VI), publishing notices of impending procurements (Article VII), time periods for publicity (Article XI), setting nondiscriminatory conditions for qualifying suppliers (Articles VIII and IX), nondiscriminatory technical requirements (Art. X), electronic reverse auctions (Article XIV), disclosing sensitive information (Article XVII), and domestic review (bid protests) (Article XVIII). It is important to note that Article V of the GPA permits developing nations to negotiate "differential treatment" from other parties, including more liberal domestic preferences and offsets; these limited exceptions are intended to entice developing nations to join the agreement.

The coverage schedules included with the GPA vary by party. The official schedules, as agreed to by the parties on March 30, 2012, are included in WTO Document No. GPA/113. ${ }^{74}$ The schedules, set forth in Appendix I to the GPA, are structured uniformly, party by party:

- Annex 1 lists covered central government entities.

- Annex 2 lists covered sub-central entities (e.g., U.S. states).

- Annex 3 lists all other covered entities.

- Annex 4 lists the goods covered by the GPA.

- Annex 5 lists covered non-construction services.

- Annex 6 lists covered construction (works) services.

- Annex 7 includes general notes.

For those working in U.S. procurement, certain aspects of the U.S. annexes to the GPA bear special emphasis. Although Annex 1 covers essentially all U.S. federal agencies, Annex 1 excludes a number of products from coverage; those products, such as textiles and specialty metals purchased by the Department of Defense, are traceable to special domestic preferences in U.S. law, or are categories (such as nuclear weapons) protected for national security reasons.

\footnotetext{
${ }^{74}$ Adoption of the Results of the Negotiations Under Article XXIV:7 of the Agreement on Government Procurement, Following Their Verification and Review, As Required by the Ministerial Decision of 15 December 2011 (GPA/1 12), Paragraph 5 -- Action Taken by the Parties to the WTO Agreement on Government Procurement at a Formal Meeting of the Committee, At the Level of Geneva Heads of Delegations, on 30 March 2012, WTO Doc. No. GPA/113 (Apr. 2, 2012), available at www.wto.org. The integrated WTO Government Procurement Market Access Information Resource (e-GPA) portal -- an online searchable compendium of the schedules, thresholds and other criteria -- affords ready access to the coverage schedules agreed to by the individual parties, and is available through https://www.wto.org/english/tratop_e/gproc_e/gp_app_agree_e.htm.
} 
The United States' Annex 2 includes only 37 states, as not all states have joined the GPA. The missing states, and the uneven coverage among the included states, have been sore points in ongoing negotiations between the European Union and the United States, discussed below. In Annexes 4 and 5, the United States has taken a "negative list" approach, i.e., only those goods and services explicitly excluded by the United States are not covered; the rest of the procurements by covered agencies are presumptively included, subject to any other special exceptions. Finally, Annex 7, the General Notes, includes important exceptions, including a reservation for preferences afforded U.S. small and minority-owned businesses. In practice this excludes roughly one quarter of U.S. federal procurement from the open market commitments made under the GPA, because by law federal agencies are to set aside at least 23 percent of federal procurement for small businesses.

Accession to the GPA should give a party's suppliers enforceable access to other parties' government procurement markets, and should improve competitiveness and efficiency in a party's government procurement market because GPA lends confidence to prospective bidders that a GPA member will provide reliable access to its procurement market. Joining the GPA also demonstrates a nation's commitment to international best practices in government procurement. $^{75}$

\section{B. The North American Free Trade Agreement (NAFTA)}

The North American Free Trade Agreement (NAFTA), a regional trade agreement between the United States, Canada and Mexico, passed into law in the United States in $1994{ }^{76}$

\footnotetext{
${ }^{75}$ See, e.g., Joshua I. Schwartz, International Protection of Foreign Bidders Under GATT/WTO Law: Plurilateral Liberalization of Trade in the Public Procurement Sector and Global Propagation of Best Procurement Practices (draft book chapter), Chapter 3, p. 82.

76 See Christopher R. Yukins, International Protection of Free Trade in Procurement under NAFTA's Chapter 10 on Public Procurement: The Pathway from NAFTA to the WTO Government Procurement Agreement to a Potential European-US Transatlantic Trade and Investment Partnership (draft book chapter, on file with author), Chapter 4, p. 1.
} 
it was intended to reduce trading costs, increase business investment, and more broadly help North America be more competitive in the global marketplace. ${ }^{77}$ Chapter 10 of NAFTA contains requirements for each NAFTA party to open up government procurement markets by way of "non-discriminatory "national' treatment" on "goods and services from suppliers from the other NAFTA countries." In order to ensure transparency, effectiveness and fairness in procurements falling under the agreement, NAFTA contains certain requirements that must be complied with by each party.

Later trade agreements that address procurement, however, have largely displaced NAFTA in U.S. law and policy. NAFTA's procurement-related provisions were never finalized, and after 1994 the World Trade Organization (WTO) Agreement on Government Procurement (GPA) played a much more central role in opening international procurement markets, both in the United States and in other countries. ${ }^{78}$ Finally, with the publication in late 2015 of the Trans-Pacific Partnership (TPP) (discussed below), it appeared that NAFTA's procurement provisions may be completely supplanted: through side letters, NAFTA members Canada, the United States and Mexico have agreed that Chapter 10 of NAFTA, on procurement, will be superseded by TPP's new protections (discussed below). ${ }^{79}$

\section{Free Trade Agreements (FTAs)}

The United States has concluded a number of bilateral and regional Free Trade Agreements (FTAs) which address procurement. Current FTAs which address procurement

\footnotetext{
77 About News, History of NAFTA, http://useconomy.about.com/od/tradepolicy/p/NAFTA_History.htm, accessed on 21st December 2015.

78 NAFTA members the United States and Canada are members of the GPA; Mexico, notably, is not.

${ }^{79}$ See Jean Heilman Grier, TPP Procurement: Harmonizing FTAs (Jan. 12, 2016), http://trade.djaghe.com/?p=2364.
} 
include agreements with Chile, ${ }^{80}$ Singapore,${ }^{81}$ Australia, ${ }^{82}$ Morocco,${ }^{83}$ CAFTA-DR ${ }^{84}$ (covering certain Central American nations and the Dominican Republic), Bahrain, ${ }^{85}$ Oman, ${ }^{86}$ Peru, ${ }^{87}$ South Korea, ${ }^{88}$ Colombia, ${ }^{89}$ Panama, ${ }^{90}$ and Israel (the earliest of these FTAs). ${ }^{91}$ These agreements generally include procurement-related terms which mirror the terms of the GPA. ${ }^{92}$ Nor is the United States the only nation negotiating such bilateral trade agreements that touch on procurement: other agreements involving other nations, such as the Comprehensive Economic and Trade Agreement (CETA) between Canada and the European Union, also include new provisions intended to open international procurement markets. ${ }^{93}$

${ }^{80}$ See FAR Part 25.400(a)(2)(ii) (referencing United States-Chile Free Trade Agreement, as approved by Congress in the United States-Chile Free Trade Agreement Implementation Act (Pub. L. 108-77) (19 U.S.C. 3805 note)).

${ }^{81}$ See FAR 25.400(a)(2)(iii) (referencing United States-Singapore Free Trade Agreement, as approved by Congress in the United States-Singapore Free Trade Agreement Implementation Act (Pub. L. 108-78) (19 U.S.C. 3805 note)).

${ }^{82}$ See FAR 25.400(a)(2)(iv) (referencing United States-Australia Free Trade Agreement, as approved by Congress in the United States-Australia Free Trade Agreement Implementation Act (Pub. L. 108-286) (19 U.S.C. 3805 note)).

${ }^{83}$ See FAR 25.400(a)(2)(v) (referencing United States-Morocco Free Trade Agreement, as approved by Congress in the United States-Morocco Free Trade Agreement Implementation Act (Pub. L. 108-302) 19 U.S.C. 3805 note)).

${ }^{84}$ See FAR 25.400(a)(2)(vi) (referencing Dominican Republic-Central America-United States Free Trade Agreement, as approved by Congress in the Dominican Republic-Central America-United States Free Trade Agreement Implementation Act (Pub. L. 109-53) (19 U.S.C. 4001 note)). The CAFTA-DR agreement includes Costa Rica, the Dominican Republic, El Salvador, Guatemala, Honduras, and Nicaragua. https://ustr.gov/tradeagreements/free-trade-agreements/cafta-dr-dominican-republic-central-america-fta.

${ }^{85}$ See FAR 25.400(a)(2)(vii) (referencing United States-Bahrain Free Trade Agreement, as approved by Congress in the United States-Bahrain Free Trade agreement Implementation Act (Pub. L. 109-169) (19 U.S.C. 3805 note)).

${ }^{86}$ See FAR 25.400(a)(2)(viii) (referencing United States-Oman Free Trade Agreement Implementation Act (Pub. L. 109-283) (19 U.S.C. 3805 note)).

87 See FAR 25.400(a)(2)(ix) (referencing United States-Peru Trade Promotion Agreement Implementation Act (Pub. L. 110-138) (19 U.S.C. 3805 note)).

${ }^{88}$ See FAR 25.400(a)(2)(x) (referencing United States-Korea Free Trade Agreement Implementation Act (Pub. L. 112-41) (19 U.S.C. 3805 note)).

89 See FAR 25.400(a)(2)(xi) (referencing United States-Colombia Trade Promotion Agreement Implementation Act (Pub. L. 112-42) (19 U.S.C. 3805 note)).

90 See FAR 25.400(a)(2)(xii) (referencing United States-Panama Trade Promotion Agreement Implementation Act (Pub. L. 112-43) (19 U.S.C. 3805 note)).

91 See FAR 25.400(a)(5) (referencing U.S.-Israel Free Trade Area Agreement, as approved by Congress in the United States-Israel Free Trade Area Implementation Act of 1985 (19 U.S.C. 2112 note)); Guy T. Petrillo, Free Trade Area Agreements and U.S. Trade Policy, 18 N.Y.U. J. Int'l L. \& Pol. 1281 (1986) (discussing U.S.-Israel agreement).

92 See Scott Sheffler, A Balancing Act: State Participation in Free Trade Agreements with "Sub-Central" Procurement Obligations, 44 Pub. Cont. L.J. 713, 719 (2015).

${ }^{93}$ See, e.g., Brenda C. Swick, The New European Procurement Directives: A Critical Perspective -- Part II: Impact of the Canada-EU Comprehensive Economic and Trade Agreement on Government Contracting in 


\section{Trans-Pacific Partnership (TPP)}

The Trans-Pacific Partnership (TPP) is multilateral trade agreement between the United States and other Pacific Rim countries -- Australia, Brunei Darussalam, Canada, Chile, Japan, Malaysia, Mexico, New Zealand, Peru, Singapore, and Vietnam -- concluded in October 2015, which was heading towards possible congressional action as of this writing. ${ }^{94}$ This agreement has been called the "cornerstone of the Obama Administration's economic policy in the Asia Pacific." 95

Chapter 15 of the TPP is dedicated to government procurement, and establishes requirements for "transparent, predictable, and non-discriminatory rules" of access to each party's government procurement markets. ${ }^{96}$ Much like the other international agreements discussed above, the TPP parties commit to afford national treatment and non-discrimination for goods and services from each party, and to comply with certain procedural rules to ensure open procurement markets. Unlike the GPA, the TPP includes a specific provision, Article $15.18,{ }^{97}$ which would encourage parties to exclude corrupt contractors and to address conflicts

Canada, 2014 Gov't Contracts Year in Review Briefs 4 (Thomson Reuters Feb. 2014); Jean Heilman Grier, EU \& Canada: Preparing to Sign Trade Pact (Aug. 9, 2016), http://trade.djaghe.com/?p=3169.

94 See Adam Behsudi, Obama Puts Congress on Notice: TPP Is Coming, Politico, Aug 12, 2016, http://www.politico.com/story/2016/08/obama-congress-trade-warning-226952; Office of the United States Trade Representative, Executive Office of the President, Summary of the Trans-Pacific Partnership Agreement, https://ustr.gov/about-us/policy-offices/press-office/press-releases/2015/october/summary-trans-pacific-

partnership, accessed on 29th December 2015. The Obama administration's draft Statement of Administration Action, https://ustr.gov/sites/default/files/DRAFT-Statement-of-Administrative-Action.pdf, delivered in August 2016 to signal the start of congressional review, explained (at pages 32-22) that the TPP would preserve existing environmental and labor/employment protections in procurement.

${ }_{95}$ Office of the United States Trade Representative: Executive Office of the President, Trans-Pacific Partnership $(T P P)$, https://ustr.gov/trade-agreements/free-trade-agreements/trans-pacific-partnership.

96 Office of the United States Trade Representative: Executive Office of the President, Summary of the TransPacific Partnership Agreement, https://ustr.gov/trade-agreements/free-trade-agreements/trans-pacificpartnership/tpp-full-text.

${ }^{97}$ The TPP article states:

Article 15.18: Ensuring Integrity in Procurement Practices

Each Party shall ensure that criminal or administrative measures exist to address corruption in its government procurement. These measures may include procedures to render ineligible for participation in the Party's procurements, either indefinitely or for a stated period of time, suppliers that the Party has 
of interest in procurement. Anti-corruption provisions such as these, which relate only indirectly to trade, reflect a broadening role for trade agreements: as benchmarks for best practices in procurement.

\section{E. Caribbean Basin Initiative}

The Caribbean Basin Initiative (CBI) is not a trade agreement, but instead a trade initiative to spur economic development; it remains an important part of relations between the United States, Central America and the Caribbean nations. ${ }^{98}$ The main purpose of this initiative is to promote "economic development and export diversification of the Caribbean Basin economies." ${ }^{99}$ Under the CBI, barriers to the U.S. market -- including the federal procurement market -- are radically reduced for beneficiary countries.

The CBI is addressed in federal procurement through regulation, at FAR 25.405. Under that provision, Caribbean Basin country end products, construction material and services for any type of acquisition that would be covered by the GPA must be treated as "eligible products," i.e., cannot be discriminated against by U.S federal purchasers. ${ }^{100}$

Years after the CBI was put in place, a number of its member nations joined CAFTADR, which as noted is a regional FTA. To reconcile the CBI with the regional free trade agreement in the Caribbean and Central America, CAFTA-DR, nations which join CAFTADR may no longer be eligible for the benefits of the CBI. ${ }^{101}$

determined to have engaged in fraudulent or other illegal actions in relation to government procurement in the Party's territory. Each Party shall also ensure that it has in place policies and procedures to eliminate to the extent possible or manage any potential conflict of interest on the part of those engaged in or having influence over a procurement.

98 Office of the United States Trade Representative: Executive Office of the President, Caribbean Basin Initiative, https://ustr.gov/issue-areas/trade-development/preference-programs/caribbean-basin-initiative-cbi; Francis W. Foote, The Caribbean Basin Initiative: Development, Implementation and Application of the Rules of Origin and Related Aspects of Duty-Free Treatment, 19 Geo. Wash. J. Int'1 L. \& Econ. 245, 248 (1985).

99 Id.

100 FAR Part 25.405.

101 Id. 


\section{F. Least Developed Countries}

Much as with the Caribbean Basin nations, federal procurement regulations make special provision for least developed countries, allowing vendors from those nations broad access to the federal procurement market. Least developed countries are classified by the United Nations based on three criteria - income, a human assets index (HAI), and an economic vulnerability index (EVI). ${ }^{102}$ Specific indicators (such as a per capita gross national income of less than roughly US\$1200) are assessed to determine whether a country qualifies for this category. ${ }^{103}$ As of December 2015, 48 countries qualified. ${ }^{104}$ FAR 25.003 lists the least developed countries given special treatment by U.S. rules, ${ }^{105}$ and FAR 25.404 provides that "[f]or acquisitions covered by the WTO GPA, least developed country end products, construction material, and services must be treated as eligible products."

\section{G. Reciprocal Defense Procurement Agreements}

The market-opening measures discussed above center around the goods and services covered by the GPA, which for many nations covers primarily civilian goods and services. ${ }^{106}$ In a separate initiative regarding defense materiel, the U.S. Department of Defense has signed reciprocal defense procurement agreements, in the form of memoranda of understanding (MOUs) or international agreements, with its counterpart ministries of defense in several

\footnotetext{
${ }^{102}$ UN Office of the High Representative for the Least Developed Countries, Landlocked Developing Countries and Small Island Developing States, Criteria for Identification and Graduation of LDCs, http://unohrlls.org/about-ldcs/criteria-for-ldcs/.

103 Id.

104 See http://www.un.org/en/development/desa/policy/cdp/ldc/ldc_list.pdf.

${ }^{105}$ FAR 25.003 defines "least developed" countries to include: Afghanistan, Angola, Bangladesh, Benin, Bhutan, Burkina Faso, Burundi, Cambodia, Central African Republic, Chad, Comoros, Democratic Republic of Congo, Djibouti, Equatorial Guinea, Eritrea, Ethiopia, Gambia, Guinea, Guinea-Bissau, Haiti, Kiribati, Laos, Lesotho, Liberia, Madagascar, Malawi, Mali, Mauritania, Mozambique, Nepal, Niger, Rwanda, Samoa, Sao Tome and Principe, Senegal, Sierra Leone, Solomon Islands, Somalia, South Sudan, Tanzania, Timor-Leste, Togo, Tuvalu, Uganda, Vanuatu, Yemen, and Zambia.

${ }^{106}$ See Allen B. Green, supra note 6, § 2:40, The consequences of the "Defense Exemption."
} 
countries. ${ }^{107}$ These reciprocal agreements enhance national security by furthering alliancewide security objectives and easing armaments cooperation. ${ }^{108}$ As is the case for other trade agreements, these reciprocal defense procurement agreements call for the signatories to act bilaterally to remove trade barriers regarding defense materiel. ${ }^{109}$ A nation which enters into such a reciprocal agreement with the Department of Defense is as a "qualifying country" under the Defense Federal Acquisition Regulation Supplement (DFARS), ${ }^{110}$ and qualifying country products are afforded the same treatment as domestic products in Defense Department procurement. ${ }^{111}$ Under these reciprocal defense agreements, as implemented through the DFARS, the Department will, among other things, waive the Buy American Act and will work to ensure that U.S. technical requirements are not unduly restrictive towards supplies from “qualifying nations"; ${ }^{112}$ U.S. vendors are to enjoy reciprocal access to counterparts' defense markets.

\section{H. The Transatlantic Trade \& Investment Partnership (TTIP) -- and the Road Ahead}

At the time of this writing, the United States and the European Union were engaged in extended negotiations over the Transatlantic Trade and Investment Partnership (TTIP), which

\footnotetext{
107 See generally Government Accountability Office (GAO), Federal Procurement: International Agreements Result in Waivers of Some U.S. Domestic Source Restrictions GAO-05-188 (Jan 26, 2005), http://www.gao.gov/products/GAO-05-188; Drew B. Miller, Note, Is It Time to Reform Reciprocal Defense Procurement Agreements?, 39 Pub. Cont. L.J. 93, 96 (2009); Christopher R. Yukins, Feature Comment: The European Defense Procurement Directive: An American Perspective, 51 Gov't Contractor II 383 (Nov. 4, 2009). 108 Allen B. Green, supra note 6, $\$ 2: 21$, The development of international free trade in government contractsUnited States bilateral defense trade memoranda of understanding.

109 The U.S. reciprocal defense procurement agreements are posted online at http://www.acq.osd.mil/dpap/cpic/ic/reciprocal_procurement_memoranda_of_understanding.html.

${ }^{110}$ DFARS 225.003(10). Currently, the qualifying countries are: Australia, Austria, Belgium, Canada, Czech Republic, Denmark, Egypt, Finland, France, Germany, Greece, Israel, Italy, Luxembourg, Netherlands, Norway, Poland, Portugal, Spain, Sweden, Switzerland, Turkey, and United Kingdom of Great Britain and Northern Ireland. Id.

111 See 252.225-7001, Buy American and Balance of Payments Program (implementing clause).

112 DFARS 225.872-1 and -3.
} 
is to include a chapter on procurement. ${ }^{113}$ While there has been heated debate on TTIP (and other trade agreements) in the 2016 U.S. election cycle, there is a significant chance that TTIP may, in time, be adopted to create a new free trade area between the United States and Europe. Although the draft TTIP agreement has not been officially released, a draft of the TTIP agreement which was leaked by Greenpeace Netherlands ${ }^{114}$ suggested that TTIP's government procurement terms will largely mirror those of the GPA. Early indications are, though, that the European Union and the United States may go a step farther in TTIP, and establish a forum for EU-U.S. regulatory cooperation regarding procurement (and other areas) to reduce regulatory barriers to trade. ${ }^{115}$ Regulatory cooperation would mark a third means of opening procurement markets, beyond nondiscrimination commitments and beyond the process requirements normally included in free trade agreements.

\section{Closing Observations}

As the discussion above reflects, the regulatory scheme in this area is inherently complex, for international trade rules and procurement regulations do not mesh gracefully. International trade agreements, which often reflect decades of painful compromise, are far too ornate to carry easily into a procurement system. At the same time, constantly evolving procurement systems are difficult to rationalize by international agreement.

\footnotetext{
113 See generally Jean Heilman Grier, TTIP Procurement Data Debate: Time to Conclude? (July 12, 2016), http://trade.djaghe.com/?p=3063; Christopher R. Yukins \& Hans-Joachim Priess, Feature Comment: Breaking the Impasse in the Transatlantic Trade and Investment Partnership (TTIP) Negotiations: Rethinking Priorities in Procurement, 56 Gov't Contr. \} 2 3 5 \text { (July 24, 2014); Daniel E. Schoeni, A Hidden Statutory Bar to Private Causes } of Action for Breaches of the WTO's Agreement on Government Procurement, 37 U. Pa. J. Int'1 L. 295, 305 (2015); Kevin McNiff, The Use of Federal Grant-Making Power to Expand State and Local Procurement Coverage Under the Transatlantic Trade and Investment Partnership, 44 Pub. Cont. L.J. 327 (2015).

114 https://www.ttip-leaks.org/.

115 See Christopher R. Yukins, Testimony Submitted to the European Parliament Committee on the Internal Market and Consumer Protection and the Committee on International Trade, for the Joint Public Hearing on TTIP: Public Procurement -- Challenges and Opportunities for the European Union and the United States, Apr. 20, 2016, https://www.law.gwu.edu/sites/www.law.gwu.edu/files/downloads/Yukins\%20Testimony.pdf.
} 
Even when an international agreement does resolve a trade barrier in procurement, that solution may not be readily enforceable under U.S. law. For example, although (as noted) Article $\mathrm{X}$ of the GPA prohibits technical requirements that are either intentionally or in effect barriers to trade, if that provision has not been incorporated directly into U.S. statutes or regulations a vendor may not be able to enforce it, either because of a formal bar to enforcement $^{116}$ or because of a reluctance on the part of oversight authorities (a court or GAO) to enforce an international agreement without clear support in U.S. law.

Those pressing to resolve a trade barrier in procurement can, though, take an alternative route, by looking to traditional notions of maximum practicable competition to fill the enforcement gap. Under basic principles of procurement law, an agency may not impose a technical requirement that unreasonably limits competition in a procurement. ${ }^{117}$ That rule, which is readily enforceable under U.S. law, may offer an alternative means of opening competition when (for practical or legal reasons) an international agreement cannot be brought to bear. That said, because the challenged agency need only proffer a "reasonable" basis for a restrictive requirement, and because the traditional analysis may not capture the broader concerns implicated by an international agreement -- the need for harmonized rules across markets, for example -- relying on domestic rules of open competition may not be enough, in the long run.

Those challenging barriers to the U.S. procurement market also should recognize the cultural and legal conflicts (and overlaps) between systems. For example, while there is often a bias in the U.S. system to "buy national," that type of economic nationalism emerges in other

\footnotetext{
${ }^{116}$ See, e.g., supra note 59 (discussing "treaty bar"); Daniel Schoeni, supra note 113 (discussing statutory bar to enforcing state obligations under the GPA).

${ }^{117}$ See, e.g., 1120 Vermont Ave. Associates, LLP, Comp. Gen. B-413019 (Aug. 1, 2016) (“'In preparing a solicitation, a contracting agency is required to specify its needs in a manner designed to achieve full and open competition, and may include restrictive requirements only to the extent they are necessary to satisfy its legitimate needs.” (citing 41 U.S.C. § 3306(a)(1)(A), (a)(2)).
} 
nations, as well. European trade statistics, which show that there is relatively little cross-border procurement in Europe, ${ }^{118}$ suggest that this bias is endemic to procurement, and not a uniquely "American" phenomenon. It is also worth noting that while the highest institutions in EU governance (including the European Commission and the Court of Justice for the European Union) tend to be the strongest proponents of opening European procurement markets (as part of a broader effort to integrate Europe), pressure to open the U.S. system to international competition may instead come from operational managers, such as contracts managers and program personnel who favor broader competition in order to ensure that the government purchases best value.

Finally, it is important to understand the basic changes underway in international agreements regarding procurement. The market-opening rules traditionally developed under international trade agreements have sometimes proven inadequate, because of the difficulties in applying and enforcing those rules. As a result, a new approach may gain momentum in the coming years: a new effort among procurement regulators from different nations to converse and cooperate, to reduce trade barriers in procurement. By drawing together regulators from different national procurement systems, this cooperative approach -- which is only now emerging -- may make efforts to open international procurement markets more practical and political, more based on common rules grounded in acknowledged best practices, and less legal and formalistic.

\footnotetext{
${ }^{118}$ See, e.g., Zornitsa Kutlina-Dimitrova \& Csilla Lakatos, Determinants of Direct Cross-Border Public Procurement in EU Member States, at 5, European Commission - Chief Economist Notes, No. 2 (July 2014), http://trade.ec.europa.eu/doclib/docs/2014/july/tradoc_152700.pdf.
} 